\title{
TNF Receptor Family Gene
}

National Cancer Institute

\section{Source}

National Cancer Institute. TNF Receptor Family Gene. NCI Thesaurus. Code C21165.

Human TNF Receptor Family Genes encode transmembrane receptor proteins regulated by TNF Family ligands. TNF receptors typically contain intracellular death domains involved in the formation of a signal transducing death-inducing complex that includes FADD and caspases that trigger an apoptotic caspase cascade. Some TNF receptors can activate NF-Kappa-B, MAPK3/ERK1, MAPK8/JNK, BIRC1, BIRC2, BAG4/SODD, TRADD, or TRAF2 and transduce inflammation or anti-apoptotic proliferating signals. Some TNF Family Receptors act as competitive decoy receptors in bone resorption or suppress FasL- and LIGHT-mediated cell death. (NCl) 